JACEK REGINIA-ZACHARSKI

Uniwersytet Łódzki

ORCID: 0000-0002-1939-1246

e-mail: jacek.reginia@uni.lodz.pl

\title{
Obszary bezpieczeństwa Inicjatywy Trójmorza
}

\section{Security areas of the Three Seas Initiative}

Słowa kluczowe:

Inicjatywa Trójmorza, bezpieczeństwo, współpraca regionalna, energetyka
Keywords:

The Three Seas

Initiative, security, regional cooperation, energy 


\section{Security areas of the Three Seas Initiative}

The Three Seas Initiative (TSI) is a relatively young format of regional cooperation, partially implemented by the instruments of the European Union. The areas of the Initiative's activity declared in Dubrovnik (2016): logistic and transport cooperation, energy cooperation as well as IT and telecommunication cooperation are immanent components of national and international security. At the same time, they implement security postulates directly or indirectly, increasing the potential and possibilities in other areas.

The aim of the study is to demonstrate the relationship between the activities carried out in the TSI format and security understood today - both in its "positive" and "negative" dimensions. The leading hypothesis is the assumption that by increasing the civilizational and infrastructural potential, levelling the development backwardness and the competitiveness of the region, it increases the level of security of the whole region, as well as of international institutions such as the European Union and NATO. 


\section{Wprowadzenie}

nicjatywa Trójmorza formalnie została ogłoszona przez prezydenta Rzeczypospolitej Polskiej Andrzeja Dudę i prezydent Chorwacji Kolindę Grabar-Kitarović na szczycie grupy inicjatywnej w Dubrowniku w dniach 25-26 sierpnia 2016 r. Początki współpracy w tym formacie datują się jednak przynajmniej od roku 2015. Podczas XXV Forum Ekonomicznego w Krynicy padły słowa o potrzebie zacieśniania współpracy w regionie, a pod koniec września w Nowym Jorku doszło do przyjęcia pierwszych ustaleń roboczych. Niemniej to szczyt w Dubrowniku wskazywany jest jako początek współpracy 12 państw $^{1}$ leżących między Bałtykiem, Adriatykiem i Morzem Czarnym. Wówczas zarysowane zostały główne perspektywy/filary współpracy: logistyczno-transportowa, energetyczna i informatyczno-telekomunikacyjna ${ }^{2}$. W tym pierwszym obszarze od samego początku jednym z głównych postulatów było utworzenie transportowej osi północ-południe (np. Via Carpatia), rozwój komunikacji cyfrowej itd. W deklaracji z Dubrownika warto podkreślić kilka elementów. Już w pierwszym akapicie zwrócono uwagę na "geopolityczny" wymiar współpracy, której efektem miałoby się stać przezwyciężenie tradycyjnego modelu horyzontalnych osi przepływu (wschód-zachód) i zbudowanie ich wertykalnej alternatywy bądź uzupełnienia (północ-południe). Współpraca w ramach Trójmorza została wyraźnie sformatowana jako inicjatywa wewnątrzunijna, korzystająca z narzędzi UE oraz obliczona na wzmocnienie Unii. Jakkolwiek dostrzegano szerszy kontekst perspektyw współpracy, podkreślony został zamiar unikania „[...] tworzenia struktur równoległych wobec istniejących już mechanizmów współpracy". Na koniec, choć nie wybrzmiało to mocno, w deklaracji jako cel ogólny działań, obok „konkurencyjności”, wskazano wzmacnianie bezpieczeństwa („[...] Europa Środkowa i Wschodnia staną się bardziej bezpieczne"). Jednocześnie trzeba podkreślić, że u zarania formułowania mechanizmów Inicjatywy unikano skojarzeń z „geopolitycznymi” poprzednikami tej koncepcji - przede wszystkim

1 Austria, Bułgaria, Chorwacja, Czechy, Estonia, Litwa, Łotwa, Polska, Rumunia, Słowacja, Słowenia i Węgry.

2 Wspólna deklaracja w sprawie Inicjatywy Trójmorza, prezydent.pl [online], 25 VIII 2016 [dostęp: 17 VIII 2020], dostępny w internecie: <https://www.prezydent.pl/ aktualnosci/wizyty-zagraniczne/art,105,wspolna-deklaracja-w-sprawie-inicjatywytrojmorza.html>. 
z ideą Międzymorza, wskazując na pragmatyczny i praktyczny charakter Trójmorza. Zaplanowane ono zostało jako „nieformalna platforma” współpracy regionalnej. Charakterystyczne na tym etapie było zatem podkreślanie dystansowania się od aspiracji instytucjonalizacji Inicjatywy i kierowania się w stronę budowy organizacji międzynarodowej.

Znaczenie Inicjatywy Trójmorza można badać przez pryzmat jej potencjału jako specyficznego podsystemu, spinającego możliwości państw, regionalnych instytucji międzynarodowych, mniej lub bardziej sformalizowanych reżimów, mechanizmów obecnych w istniejących systemach nadrzędnych (np. Unia Europejska). W zakresie zakorzenienia metodologicznego podstawowym pytaniem wydaje się kwestia "stawki” w grze. W kategoriach politycznych jest nią z pewnością zwiększenie potencjału i zdolności do suwerennego kształtowania własnego bezpieczeństwa, rozumianego jako zapewnienie możliwości przetrwania i rozwoju. $\mathrm{W}$ istocie zagadnienia te dotyczą problematyki potęgi i jako takie sytuują problem $\mathrm{w}$ domenach związanych $\mathrm{z}$ paradyǵmatem realistycznym - szczególnie zaś jego nurtów strukturalnych i defensywnych. Jednak odpowiedzi na identyfikowane zagrożenia, wyzwania i ryzyka, przyjmowane strategie - $\mathrm{w}$ tym również te dotyczące szans - budowane są na podstawie modeli kooperacyjnych. Wydaje się zatem, że podejścia neoliberalne powinny być również uwzględnione.

Samo bezpieczeństwo należy rozumieć szeroko, zarówno w wymiarze przedmiotowym, jak i jakościowym. W tym pierwszym znalazły się płaszczyzny logistyczno-transportowa, energetyczna i informatyczno-telekomunikacyjna. Jakkolwiek aspekty militarne nie są istotnie eksponowane lub nie pojawiają się wcale, powinny zostać również wzięte pod uwagę z dwóch co najmniej powodów. Po pierwsze, wyznaczone płaszczyzny współpracy wymagają osłony wojskowej, a ta konieczność implikuje uruchomienie kooperacji w tej dziedzinie. Po drugie, jak pisano wcześniej, Trójmorze ma stanowić platformę do koordynacji współpracy również na poziomie formatów międzynarodowych obecnych i aktywnych w regionie. Tu należy wskazać Bukareszteńską Dziewiątkę ${ }^{3}$, Sojusz Północnoatlantycki czy dwustronne, realizowane „wachlarzowo" inicjatywy obronne ze Stanami Zjednoczonymi.

3 K. Pawłowski, Bukareszteńska Dziewiątka: współpraca państw wschodniej flanki NATO, „IEŚ Policy Papers” 2020, nr 4 [online, dostęp: 17 X 2020], dostępny w internecie: 〈https://ies.lublin.pl/pub/publikacje/policy-papers/ies-policy-papers-4-4-2020.pdf〉. 
W wymiarze jakościowym realizacja postulatów bezpieczeństwa odpowiada oczywiście postulatom „od” (bezpieczeństwo negatywne), ale przede wszystkim bezpieczeństwu "do" (bezpieczeństwo pozytywne). Na bezpieczeństwo składają się zdolności zapewnienia przeżycia oraz "przeżycie plus”, gdzie „plus" oznacza pewną wolność podejmowania żywotnych wyborów, po zapewnieniu trwałości egzystencjalnej ${ }^{4}$. W literaturze tę dychotomię określa się również nieco precyzyjniej jako bezpieczeństwo od i bezpieczeństwo do 5 . Bezpieczeństwo może być rozumiane jako produkt osiągany w efekcie zdolności dysponowania określonym zasobem. W tej perspektywie potęga/potencjał jest drogą do bezpieczeństwa: im więcej potencjału (szczególnie siły wojskowej) państwo może zóromadzić, tym bardziej jest bezpieczne $e^{6}$.

Inne podejście zakłada, że bezpieczeństwo jest funkcją stabilności społecznej ${ }^{7}$. Wiąże się to z troską o sprawiedliwość społeczną, respektowaniem interesów poszczególnych części zbiorowości oraz zrozumienia dla interesów wspólnych. Bezpieczeństwo jest raczej relacją między różnymi podmiotami niż produktem potęgi ${ }^{8}$. Można je postrzegać $\mathrm{w}$ kategoriach negatywnych (bezpieczeństwo dotyczy braku czynnika zagrażającego) lub pozytywnych (obejmujących zjawiska, które umożliwiają osiąganie celów). To rozróżnienie jest często odzwierciedlone w ideach wolności od i wolności $d o^{9}$. Bezpieczeństwo polega zatem na uzyskaniu pewnego stopnia społecznej akceptacji celów, która wynika ze współdzielenia się świadomymi

4 K. Booth, Theory of World Security, Cambridge University Press, Cambridge 2007, s. 102-103.

5 D. P. Barash, Ch. P. Webel, Peace and Conflict Studies, SAGE, Thousand Oaks 2014, s. 7-8; P. Lawler, Peace Studies, Security Studies: An Introduction, ed. P. D. Williams, Routledge, Abingdon-New York 2008, s. 82-83; H. Shue, Basic Rights, [w:] Contemporary Political Philosophy: An Anthology, ed. R. E. Goodin, Ph. Pettit, Blackwell, Malden-Oxford 2006, s. 302-303.

6 J. J. Mearsheimer, Reckless states and realism, [w:] Realism and World Politics, ed. K. Booth, Routledge Abingdon-New York 2011, s. 124-127; M. van Creveld, A History of Strategy: From Sun Tzu to William S. Lind, Castalia House, Kouvola 2015, s. 12-13.

7 J. Nef, Human Security and Mutual Vulnerability, International Development Research Centre, Ottawa 2002, s. 61-63.

8 B. J. Steele, Ontological Security in International Relations: Self-Identity and the IR State, Routledge, London-New York 2008, s. 35-36.

9 Świetne i kompleksowe rozważania tej dziedzinie zob.: Ph. Pettit, A Theory of Freedom: From the Psychology to the Politics of Agency, Polity Press, Cambridge 2001, s. $126 \mathrm{i} \mathrm{n.}$ 
zobowiązaniami (prawami i odpowiedzialnościami), co z kolei zapewnia pewien stopień pewności i przewidywalności. Pogląd ten dowodzi, że to nie konkretne środki (np. militarne) stanowią kluczowy czynnik w zrozumieniu „równania bezpieczeństwa i niepewności"10 , ale raczej związki i współzależności między zainteresowanymi podmiotami.

„Bezpieczeństwo" i „bezpieczeństwo "plus«" pozostają w nierozerwalnym sprzężeniu zwrotnym ${ }^{11}$. Sektor "plus” może bowiem być formułowany wyłącznie w warunkach zapewnienia bezpieczeństwa „od”/,przed”, natomiast realizacja sektora „do” (czyli bezpieczeństwa „plus”) zapewnia środki do rozwijania zdolności do obrony i ochrony podstaw egzystencjalnych w dynamicznie zmieniającym się i rywalizacyjnym środowisku.

\section{Inicjatywa Trójmorza: aspekty geopolityczne}

Nie jest przypadkiem, że Inicjatywa Trójmorza jako projekt geopolityczny weszła w fazę operacjonalizacji w latach 2015-2016. W rejonie Europy Środkowej zaznaczyła się wówczas tendencja do szukania alternatywy dla dotychczas wiodącej orientacji na centrum brukselsko-berlińskie i poszukiwania „nowej tożsamości” regionalnej. Czynnikiem głęboko warunkującym zmiany w tej części świata była wojna na Ukrainie. Efektem stało się zakończenie większości wspólnych projektów niemiecko-rosyjskich, z wyjątkiem energetycznego przedsięwzięcia w postaci Nord Stream 2. Kryzys migracyjny i stosunkowo zwarte stanowisko państw V-4 wobec wspieranej przez Republikę Federalną Niemiec koncepcji dyslokacji dało kolejny asumpt do kwestionowania rosnących wpływów RFN w Europie Środkowej i Wschodniej (ujmowanych niekiedy jako Mitteleuropa 2.0).

Zderzyły się tu niemieckie tendencje do umacniania pozycji na wschodzie Europy z rosyjskimi projektami utrzymywania limitrofów ${ }^{12}$ lub by użyć określenia Barry'ego Buzana i Ole Wævera - regionalnego

10 I. Savic, Z. C. Shirkey, Uncertainty, Threat, and International Security: Implications for Southeast Asia, Routledge, Abingdon-New York 2017, s. 4-6.

11 J. Reginia-Zacharski, Wojna w świecie współczesnym. Uczestnicy - cele - modele - teorie, Wydawnictwo Uniwersytetu Łódzkiego, Łódź 2014, s. 39-45.

12 N. A. Komleva, Limitrof kak geopolititcheskaya technologia, „Izvestia Uralskovo gosudarstvennovo universiteta”, series 1: „Problemy obrazovanija, nauki i kultury” 2010, issue 3 (78), s. 39-40; tejże, Vojny v limitrofach: evolutsia technologij, „Prosyranstvo i vremija" 2015, issue 1-2 (19-20). 
kompleksu bezpieczeństwa ${ }^{13}$. Warto tu pokusić się o uwage, że oba geopolityczne projekty (w wymiarze intelektualnym i implementacyjnym), nie są ze sobą sprzeczne. W określonych warunkach mogą być komplementarne lub neutralne. Co najwyżej można uznać, że rywalizację o skalę i zasięg wpływów w „pasie środkowoeuropejskim” oba ośrodki potęgi traktują jako narzędzie do ewentualnej poprawy własnej pozycji „negocjacyjnej” w relacjach wzajemnych ${ }^{14}$.

Przyjmując taki model rozumowania w odniesieniu do współczesnych tendencji w geopolityce regionu, należy podkreślić, że przed państwami w pasie między morzami Bałtyckim, Czarnym i Adriatyckim stają dwa scenariusze. Pierwszy stanowi jakaś forma bandwagoningu, czyli wpisania się w modus operandi Republiki Federalnej Niemiec lub/i Federacji Rosyjskiej. Drugim jest poszukiwanie możliwości utworzenia samodzielnej jakości geopolitycznej, mogącej stanowić odpowiedź i alternatywę dla Mitteleuropy 2.o lub tendencji eurazjatyckich. Na marginesie trzeba zauważyć, że balansowanie między potęgami (czyli ewentualna "trzecia droga”) nie jest programem pozytywnym i w istocie realnym, czego dowiodły przykłady (choć różniące się) Ukrainy oraz w pewnym stopniu Białorusi. Wracając do wspomnianej wcześniej pamięci instytucjonalnej, właśnie Trójmorze wydaje się konceptem spełniającym - przynajmniej potencjalnie - warunki scenariusza drugiego.

\section{Bezpieczeństwo: perspektywa logistyczno-transportowa}

„Rocznik Strategiczny” wśród wiodących przedsięwzięć o wymiarze logistyczno-transportowym wymieniał projekty Via Carpatia, Via Baltica oraz śródlądowego szlaku wodnego opartego na Odrze, wskazując, że stały się one głównie inicjatywami rządu polskiego ${ }^{15}$. Via Carpatia jako projekt

13 B. Buzan, O. Wæver, Regions and Powers: The Structure of International Security, Cambridge University Press, Cambridge 2004, s. 7 i n.

14 Potwierdzeniem tej hipotezy może być obserwacja, iż rzeczywistą przyczyną procesu, który doprowadził do wojny na Ukrainie, była rosyjska reakcja na niemal sfinalizowane podpisanie przez Ukrainę traktatu stowarzyszeniowego z UE w Rydze. Gorącym rzecznikiem tego rozwiązania była właśnie Republika Federalna Niemiec.

15 A. Bieńczyk-Missala, Polityka zagraniczna Polski w setna rocznice niepodległości, „Rocznik Strategiczny” 2018/2019, t. 24, Wydawnictwo Naukowe Scholar, Warszawa 2019, s. 322. 
strategiczny w zakresie połączeń drogowych pojawiła się w koncepcjach lansowanych przez władze Rzeczypospolitej Polskiej stosunkowo wcześnie. W 2006 r. jako konsekwencja Międzynarodowej Konferencji „Jedna droga cztery kraje" podpisana została przez ministrów transportu Węgier, Słowacji, Litwy oraz Polski deklaracja łańcucka ${ }^{16}$. Prace koncepcyjne nabrały rozmachu od 2010 r. po włączeniu się do inicjatywy Bułgarii, Rumunii oraz Grecji. Ta droga ekspresowa $z$ elementami autostrady miała ostatecznie prowadzić z Kłajpedy do Salonik, tworząc "[...] trwały i solidny kręgosłup drogowy na obszarze pomiędzy Bałtykiem, Adriatykiem, Morzem Czarnym i Morzem Egejskim"17. Poszczególne odcinki Via Carpatia są budowane i finansowane przez państwa-gospodarzy, choć istotne jej fragmenty znalazły się w Transeuropejskiej Sieci Transportowej - TEN-T ${ }^{18}$.

Wspomniana Via Baltica połączy Polskę (Warszawa) z Estonią (Tallin), przechodząc przez Litwę i Łotwę. Oprócz komplementarności wobec Via Carpatia „Droga Bałtycka” w połączeniu z linią kolejową Rail Baltica ${ }^{19}$, która ma wchodzić w skład Trans-European Transport Networks (TET-N), oraz Koleją Dużych Prędkości będzie łączyć Węgry, Słowację, Czechy oraz Polskę $\mathrm{z}$ republikami nadbałtyckimi. Ostatecznie funkcjonalność ma osiągnąć kompleks infrastrukturalny, obsługujący transport

16 Deklaracja Łańcucka, Prezydent.pl [online], 27 X 2006 [dostęp: 12 VIII 2020], dostępny w internecie: <https://www.prezydent.pl/archiwum-lecha-kaczynskiego/ aktualnosci/rok-2006/art,150,1025,deklaracja-lancucka.html $>$. Wcześniej - w marcu Lech Kaczyński rozwijał koncepcję jako komplementarną do projektów „transkarpackich" ideę Via Baltica w przemówieniu wygłoszonym w parlamencie Litwy.

17 Forum biznesu $w$ ramach Szczytu Inicjatywy Trójmorza, gov.pl, Ministerstwo Infrastruktury [online], 6 VI 2019 [dostęp: 7 X 2020], dostępny w internecie: <https:// www.gov.pl/web/infrastruktura/forum-biznesu-w-ramach-szczytu-inicjatywytrojmorza>.

18 Transeuropejska sieć transportowa - TEN-T, gov.pl, Ministerstwo Infrastruktury [online, dostęp: 17 X 2020], dostępny w internecie: <https://www.gov.pl/web/infrastruktura/transeuropejska-siec-transportowa-ten-t $\rangle$. Od 2013 roku TEN-T opiera się na idei dziewięciu korytarzy: Morze Bałtyckie - Morze Adriatyckie; Morze Północne - Morze Bałtyckie; Morze Śródziemne; Wschód/wschodnia część regionu Morza Śródziemnego; Skandynawia - Morze Śródziemne; Ren - Alpy; Atlantyk; Morze Północne - Morze Śródziemne; Ren - Dunaj.

19 W Winie o Rail Baltica, gov.pl, Ministerstwo Infrastruktury [online], 4 IV 2019 [dostęp: 30 X 2020], dostępny w internecie: <https://www.gov.pl/web/infrastruktura/ w-wilnie-o-rail-baltica>. 
i logistykę w obszarze Trójmorza, który będzie się opierał na kilku filarach. Do wcześniej wymienionych włączony został projekt wielkiego hubu logistyczno-transportowego, zlokalizowanego w Polsce - Centralnego Portu Komunikacyjnego. Całość ostatecznie opisana została podczas Szczytu Inicjatywy Trójmorza (Lublana, 5-6 czerwca 2019 r.) przez wiceministra infrastruktury Rafała Webera następująco:

Projekty Via Carpatia, Rail Baltica, Via Baltica, CPK czy Korytarz Bałtyk-Adriatyk, uzupełnione o ukończenie ciągów autostrad, poprawę dostępu do portów morskich oraz rozbudowę portów lotniczych, pozwolą stworzyć powiązaną, nowoczesną i multimodalną infrastrukturę transportową w Polsce, łączącą wschód i zachód Europy oraz północ z południem ${ }^{20}$.

Korytarz Bałtyk-Adriatyk ma stanowić ostateczny zwornik logistyczno-transportowego wymiaru Trójmorza. Przebiegający przez terytoria Polski, Czech, Słowacji, Austrii, Włoch i Słowenii, połączy porty w Gdańsku, Gdyni, Szczecinie i Świnoujściu z portami w Trieście, Wenecji, Rawennie i Koprze. Poprzez łączenie aglomeracji, terminali logistyczno-transportowych, portów wodnych i lotniczych ostatecznie powstaną bezpieczne i wydajne multimodalne łańcuchy transportowe do przewozu ludzi i towarów ${ }^{21}$.

Znaczenie niemal fundamentalne Inicjatywy Trójmorza dla bezpieczeństwa transportowego państw je współtworzących, rozumianego przede wszystkim w kategoriach „plus”, jest bezdyskusyjne. Umożliwia bowiem realizację suwerennych wyborów, nieobarczonych determinizmem polityczno-historycznym, odziedziczonym jako spuścizna lat funkcjonowania w obcych organizmach państwowych lub strefach wpływu. Doprowadził on bowiem do zdecydowanej dominacji linii komunikacyjnych o przebiegu równoleżnikowym. Budowa połączeń o przebiegu południkowym stanowi szansę na wykorzystanie potencjału rozwojowego tej części świata i solidny fundament dla rozwijania suwerennych interesów, realizowanych w warunkach kooperacji.

20 Forum biznesu $w$ ramach Szczytu...

21 Korytarz Bałtyk - Adriatyk składa się z łańcuchów: Gdynia - Gdańsk - Katowice/ Sławków, Gdańsk - Warszawa - Katowice, Katowice - Ostrawa - Brno - Wiedeń, Szczecin/Świnoujście - Poznań - Wrocław - Ostrawa, Katowice - Žilina Bratysława - Wiedeń, Wiedeń - Graz - Villach - Udine - Triest, Udine - Wenecja Padwa - Bolonia - Rawenna, Graz - Maribor - Ljubljana - Koper/Triest. 
Kontekst bezpieczeństwa wojskowego $\mathrm{w}$ wymiarze logistyczno-transportowym wydaje się oczywisty. Poczynając od ćwiczeń „Anakonda 2016”, kolejne manewry wykazywały konieczność rozwijania zdolności przerzutowych wojsk sojuszniczych na osi północ-południe. Największym testem miały być zaplanowane ćwiczenia "Defender 2020”, które odbyły się w bardzo okrojonym i ograniczonym zakresie z powodu pandemii coviD-19. Współpraca w ramach TSI stała się jednym z wątków letniego Global Forum w 2017 r. Padły tam znamienne słowa:

W szerszym kontekście regionalnym, istotna jest [...] zmiana osi, wzdłuż której rozgrywa się polityka. Myślenie w kategoriach wschód-zachód [...] nie oddaje specyfiki Europy Środkowo-Wschodniej. Inicjatywa Trójmorza [...] proponuje zupełnie inną optykę - oś północ-południe. Blok państw od Skandynawii, po Ukrainę, Bałkany [...] dysponuje znacznym potencjałem i dużym doświadczeniem współpracy dwustronnej i wielostronnej. [...] Trójmorze jest działaniem integracyjnym, pozwalającym na dopełnienie integracji $\mathrm{w}$ ramach UE. To raczej mówienie o Europach dwóch prędkości w obszarze bezpieczeństwa i rozdzielanie więzi transatlantyckiej jest dezintegracyjne i narazi Europę na niebezpieczeństwo. Bez USA, jedynego państwa, które jest w stanie przeciwstawić się potencjałowi nuklearnemu Rosji, jej obrona będzie niemożliwa ${ }^{22}$.

Od szczytu warszawskiego w 2017 r. w wymiarze symbolicznym i praktycznym Stany Zjednoczone identyfikowane są jako strategiczny partner Inicjatywy Trójmorza i innych formatów współpracy regionalnej np. Bukareszteńskiej Dziewiątki²3.

22 Przesłanie do uczestników Global Forum, gov.pl, Ministerstwo Obrony Narodowej [online], 7 VII 2017 [dostęp: 27 X 2020], dostępny w internecie: <https://www.gov. $\mathrm{pl} /$ web/obrona-narodowa/przeslanie-do-uczestnikow-global-forum-2 $\rangle$.

23 W jej skład wchodzą: Polska, Rumunia, Estonia, Litwa, Łotwa, Słowacja, Czechy, Węgry oraz Bułgaria. Początki współpracy sięgają roku 2014, a pierwsze spotkanie ministrów spraw zagranicznych tego formatu odbyło się w Bukareszcie w listopadzie 2016 r. Zob.: Eksperci: Bukaresztańska dziewiątka to cenna inicjatywa dyplomatyczna, Forsal.pl [online], 5 X 2018 [dostęp: 17 X 2020], dostępny w internecie: <https://forsal.pl/artykuly/1289699,eksperci-bukaresztanska-dziewiatka-to-cenna-i nicjatywa-dyplomatyczna.html $>$. 


\section{Bezpieczeństwo: perspektywa energetyczna}

Państwa Inicjatywy Trójmorza wykazują znaczące podobieństwa w uwarunkowaniach bezpieczeństwa energetycznego. Wszystkie one dalekie są od niezależności energetycznej i w związku z tym muszą prowadzić politykę obliczoną na zwiększenie poziomu bezpieczeństwa energetycznego w efekcie dywersyfikacji i zbalansowania dostaw. Znaczna część jako spuściznę po członkostwie w bloku sowieckim odziedziczyła słabo zmodernizowaną gospodarkę o znacznej energochłonności oraz oparcie energetyki na wysokoemisyjnych technologiach związanych z węglem czy strukturalne połączenie w zakresie infrastruktury przesyłowej gazu i ropy z Federacją Rosyjską ${ }^{24}$. W zakresie charakterystyki systemu warto też wskazać wysoki „stopień centralizacji i upaństwowienia spółek działających na rynkach"25. Wszystkie one, jako państwa członkowskie Unii Europejskiej, podlegają regulacjom ogólnounijnym z jednej strony i współtworzą politykę energetyczną UE z drugiej.

Tym wyzwaniom wychodzi naprzeciw tzw. korytarz gazowy Północ-Południe, którego realizacja będzie pozwalać na większą niezależność od zasobów energetycznych z Rosji, m.in. przez stosowanie rewersu fizycznego. Korytarz ma połączyć terminal LNG w Świnoujściu i Gazociąg Bałtycki (Baltic Pipe) z terminalem na wyspie Krk w Chorwacji ${ }^{26}$. Gazociąg Bałtycki umożliwi przesył surowca na linii Norwegia - Dania - Polska oraz rozbudowę infrastruktury w Danii, w Polsce i w Szwecji ${ }^{27}$.

Rozbudowa infrastruktury energetycznej w ramach Inicjatywy, oprócz wymiaru wspólnotowego, pozwoli realizować interesy narodowe. Bułgaria

24 S. Ascari, The Gas Target Model for the Visegrad 4 Region. Conceptual Analysis, Ośrodek Studiów Wschodnich, Warszawa, maj 2013, s. 14-17.

25 M. Ruszel, A. Kucharska, Dywersyfikacja źródeł dostaw gazu ziemnego do państw Grupy Wyszehradzkiej - wyzwania i perspektywy rozwoju, Prace IEś 2020, nr 3 [dostęp: 27 X 2020], dostępny w internecie: <https://ies.lublin.pl/prace/dywersyfikacja-zrodel-dostaw-gazu-ziemnego-do-panstw-grupy-wyszehradzkiej-wyzwania-iperspektywy-rozwoju-3-2020>.

26 Tamże, s. 53.

27 Projekt Baltic Pipe - budowa międzysystemowego Gazociagu Bałtyckiego [online, dostęp: 27 X 2020], dostępny w internecie: 〈https://www.baltic-pipe.eu/wp-content/ uploads/2019/03/3-SMDI-19022019-niechorze.pdf $>$. 
aspiruje do stworzenia regionalnego hubu gazowego ${ }^{28}$, Litwy, Łotwy i Estonii, dla których uniezależnienie ma charakter żywotnych interesów przy ewentualnej awarii terminalu LNG w Kłajpedzie lub PMG Incukalns, gdyż państwa te będą wtedy skazane na ograniczoną podaż gazu ${ }^{29}$.

Jeszcze w 2009 r. przyjęty został Baltic Energy Market Interconnection Plan, którego zadaniem jest m.in. energetyczne zabezpieczenie państw bałtyckich wraz z Finlandią ${ }^{30}$. Realizacja projektu Trójmorza w wymiarze energetycznym niewątpliwie wspiera takie inicjatywy. Choćby budowa interkonektora gazowego na linii Polska-Litwa, który zakłada budowę transgranicznego gazociągu łączącego systemy przesyłowe gazu ziemnego obu państw, wprowadza nowe możliwości. Zakłada się, że projekt ten zostanie sfinalizowany do końca $2021 \mathrm{r}^{31}$ Innym elementem korytarza Północ-Południe jest połączenie gazowe Polska - Słowacja oraz Polska - Czechy, które mają zwiększyć zdolność przesyłową międzysystemowego połączenia dzięki modernizacji i uzyskaniu zdolności rewersowej ${ }^{32}$.

Współpraca w ramach projektu energetycznego wśród państw Europy Środkowej jest istotna również ze względu na zwiększenie spójności infrastruktury, a więc służyć on będzie całemu regionowi. Ponadto „odpolitycznienie" cen gazu może być również elementem stabilizującym ten region $^{33}$. Wobec wyzwań wynikających z budowy Nord Stream 2 projekty

28 B. Bieliszczuk, Trójmorze: wspótpraca na rzecz unijneǵo i regionalneǵo rynku ǵazu, Polski Instytut Spraw Międzynarodowych, 30 VI 2017 (Biuletyn PISM, 63 (1505)), s. 1553.

29 T. Stępniewski, Inicjatywa Trójmorza: uwarunkowania geopolityczne i nowy model regionalnej współpracy, „Studia Europejskie - Studies in European Affairs” 2018, nr 2, s. 38-39.

30 Juncker Commission ends energy isolation and increases solidarity and energy security, European Commission [online, dostęp: 17 X 2020], dostępny w internecie: <https:// ec.europa.eu/energy/sites/ener/files/energy_solidarity_security.pdf $>$.

31 Przebieg zob.: Interkonektor Polska - Litwa Projekt o znaczeniu wspólnotowym realizowany przez GAZ-SYSTEM S. A. i AB Amber Grid [online, dostęp: 17 X 2020], dostępny w internecie: <https://www.gaz-system.pl/fileadmin/pliki/inwestycje/ ulotki/Interkonektor_Polska_-_Litwa.pdf $\rangle$.

32 Przebieg zob.: Gas System, [online, dostęp: 17 x 2020], dostępny w internecie: <https://www.gaz-system.pl/fileadmin/pliki/inwestycje/ulotki/Ulotka_Polska_Czechy_ zatwierdzona.pdf $>$.

33 M. Ruszel nazywa tę tendencję „odpolitycznieniem cen” na rzecz ich „urynkowienia”. 
energetyczne w ramach Trójmorza uzyskały status wspólnotowy (Projects of Common Interest - $\mathrm{PCI}^{34}$ ). PCI zakłada m.in. uproszczenie procedur biurokratycznych ${ }^{35}$ oraz umożliwia ubieganie się o dofinansowania ${ }^{36}$ ze środków Connecting Europe Facility - CEF. Warto odnotować, że w całkowitym wolumenie projektów gazowych ok. 90 proc. środków przekazywanych w ramach CEF trafia do państw Inicjatywy Trójmorza ${ }^{37}$.

Gazociąg Bałtycki stał się istotnym projektem strategicznym wchodzącym w koncepcję Korytarza Północ-Południe oraz Baltic Enegry Market Interconnection Plan ${ }^{38}$, wpisując się w ten sposób w plany rozwojowe infrastruktury energetycznej, które zostały wyznaczone przez UE. Co warte podkreślenia, w ostatnim czasie gros uwagii w tym formacie poświęca się rozbudowie energetyki wiatrowej, opartej na farmach morskich ${ }^{39}$. Multimodalność projektów bałtyckich w zakresie energetyki poza zwiększaniem operacyjności całokształtu polityki energetycznej państw uczestniczących, powoduje również „polityczne przyciąganie” państw skandynawskich do inicjatyw regionalnych, w tym Inicjatywy Trójmorza.

W „południowej” części obszaru Trójmorza rozbudowa sieci energetycznych uwzględnia takie projekty jak gazociąg BRUA o maksymalnej zdolności przesyłowej 4,4 $\mathrm{mld} \mathrm{m}^{3}$ rocznie, który stanowi część krajowego systemu

34 Regional groups and their role, European Commission [online, dostęp: $17 \mathrm{X}$ 2020], dostępny w internecie: <https://ec.europa.eu/energy/topics/infrastructure/ projects-common-interest/regional-groups-and-their-role_en $\rangle$.

35 PCI examples and their benefits, European Commission [online, dostęp: $17 \mathrm{X}$ 2020], dostępny w internecie: 〈https://ec.europa.eu/energy/topics/infrastructure/ projects-common-interest/PCI-examples-and-their-benefits_en $>$.

36 Funding for PCIs, European Commission [online, dostęp: 17 X 2020], dostępny w internecie: 〈https://ec.europa.eu/energy/topics/infrastructure/projects-common-interest/ funding-for-PCIs_en $\rangle$.

37 Projects of Common Interest, European Commission [online, dostęp: $20 \mathrm{X} 2020$ ], dostępny w internecie: <https://ec.europa.eu/energy/topics/infrastructure/ projects-common-interest_en $>$.

38 Baltic energy market interconnection plan, European Commission [online, dostęp: $20 \mathrm{X}$ 2020], dostępny w internecie: 〈https://ec.europa.eu/energy/topics/infrastructure/ high-level-groups/baltic-energy-market-interconnection-plan_sl\#documents $>$.

39 Baltic sea offshore wind joint declaration of intent [online, dostęp: $21 \times 2020$ ], dostępny w internecie: <https://ec.europa.eu/energy/sites/ener/files/signature_version_baltic_sea_offshore_wind.pdf $\rangle$. 
Rumunii, z planowanymi interkonektorami do Austrii, Bułgarii i Węgier ${ }^{40}$. Innym projektem jest otwarty w 2020 r. gazociąg Ungheni - Kiszyniów ${ }^{41}$. Wyraźny w „gazowej” rzeczywistości regionu jest podział inicjatyw na dwa/trzy obszary: bałtycki, oparty na Morzu Czarnym oraz Adriatyku, przy czym te dwa ostatnie mają już wiele elementów wspólnych. Istotą Trójmorza wydaje się dążenie do spięcia ich $\mathrm{w}$ jeden skoordynowany i zwrotny system. Nie dotyczy to oczywiście wyłącznie gazu. Rozwój innych technologii energetycznych: OzE, energetyki jądrowej i - docelowo - wodorowej sprawia, że projekt TSI wydaje się obiecującą perspektywą. Jeżeli zaś przyjąć, że bezpieczeństwo energetyczne nie sprowadza się wyłącznie do zapewnienia stałych dostaw surowców przy akceptowalnej cenie ${ }^{42}$, ale stanowi czynnik geopolityczny (geopolityka energii) ${ }^{43}$, niezbędne staje się przeniesienie refleksji na poziom interesów żywotnych. Rozbudowa infrastruktury energetycznej, skutkująca wzrostem jej złożoności i tym samym wrażliwości, powoduje konieczność „uruchomienia” kolejnego filaru współpracy trójmorskiej - tym razem w zakresie bardziej klasycznie pojmowanego bezpieczeństwa ${ }^{44}$.

40 BRUA Pipeline, European Bank for Reconstrucion and Developmnet [online, dostęp: 21 X 2020], dostępny w internecie: 〈https://www.ebrd.com/work-with-us/projects/ psd/brua-pipeline.html>.

41 EBRD invests in Ungheni-Chisinau gas pipeline, European Bank for Reconstrucion and Developmnet [online, dostęp: $21 \mathrm{X} 2020$ ], dostępny w internecie: <https://www. ebrd.com/news/2020/ebrd-invests-in-unghenichisinau-gas-pipeline.html $\rangle$.

42 C. W. Pumphre, Introduction, [w:] The Energy and Security Nexus: A Strategic Dilemma, (SSI) Carlisle, PA: November 2012, s. 2; Ch. Winzer , Conceptualizing Energy Security, „EPRG Working Paper (1123) \& Cambridge Working Paper in Economics (1151)”, July 2011, s. 2; M. Ruszel, Bezpieczeństwo enerǵetyczne Polski. Wymiar teoretyczny i praktyczny, Rambler, Warszawa 2015, s. 27; H. Nyga-Łukaszewska, Bezpieczeństwo energetyczne: u źródeł chaosu semantycznego, [w:] Bezpieczeństwo enerǵetyczne. Koncepcje, wyzwania, interesy, red. J. Gryz, A. Podraza, M. Ruszel, Wydawnictwo Naukowe PWN, Warszawa 2018, s. 69-70; A. Podraza, Problemy i zagrożenia a rozwój koncepcji bezpieczeństwa energetycznego, [w:] Bezpieczeństwo enerǵetyczne. Koncepcje..., s. 46-47.

43 M. L. O'Sullivan, The Entanglement of Energy, Grand Strategy, and International Security, [w: The Handbook of Global Energy Policy, ed. A. Goldthau, John Wiley \& Sons, Oxford 2013, s. 31-32.

44 Tomasz Stępniewski uznaje to wręcz za „[... brakujący komponent Inicjatywy Trójmorza". Zob.: T. Stępniewski, Inicjatywa Trójmorza: uwarunkowania..., s. 39-40. 


\section{Bezpieczeństwo: perspektywa informatyczno-telekomunikacyjna}

W wymiarze cyfrowym, który w hierarchii celów Inicjatywy wydaje się na razie lokowany na dalszym miejscu w stosunku do pozostałych filarów, podjęto jednak wiele istotnych inicjatyw ${ }^{45}$. "Cyfrowe Trójmorze” (Digital Three Seas Initiative - DTSI) realizować ma bowiem zadanie zwiększenia poziomu ilościowego i jakościowego cyfryzacji w regionie. Flagowym projektem jest 3 Seas Digital Highway. Już 17 września 2018 r. reprezentanci krajów Trójmorza na trzecim szczycie w Bukareszcie ${ }^{46}$ przyjęli zestaw głównych projektów strategicznych w dziedzinie energii, transportu i technologii cyfrowej ${ }^{47}$. W ramach tej ostatniej ustanowiono 3 Seas Digital Highway, integralną część DTSI jako jeden z priorytetowych projektów połączeń międzysystemowych, który ma wzmocnić bezpieczne połączenia cyfrowe na osi północ-południe. Może ona wypełnić luki w infrastrukturze komunikacyjnej, w tym w światłowodach (zarówno w warstwie szkieletowej, jak i dostępowej) oraz $\mathrm{w}$ infrastrukturze technologii $5 \mathrm{G}^{48}$. Planowana infrastruktura cyfrowa ma być realizowana wzdłuż planowanych szlaków transportowych i energetycznych Trójmorza. Innymi obszarami współpracy miały się stać działania na rzecz rozwoju podmiotów oferujących usługi bazujące na chmurze obliczeniowej i przechowywaniu danych (tzw. wyspy danych), eliminacja ryzyka dublowania infrastruktury magazynowanie zasobów cyfrowych (łączenie wysp danych), tworzenie warunków dla rozwoju gospodarki opartej na danych oraz rozbudowa infrastruktury telekomunikacyjnej wraz z inteligentnymi systemami magazynowania i odprawy

45 Inicjatywa Cyfrowego Trójmorza: wezwanie do nadania wspótpracy regionalnej silnego wymiaru cyfrowego, Instytut Kościuszki [online], vI 2018 [dostęp: 30 X 2020], dostępny w internecie: $<$ https://www.ik.orö.pl/wp-content/uploads/white-paper_inicjatywa_cyfrowego_trojmorza.pdf $\rangle$.

46 Trójmorze, gov.pl, Ministerstwo Spraw Zagranicznych [online, dostęp: 29 X 2020], dostępny w internecie: https://www.gov.pl/web/dyplomacja/trojmorze.

47 Wymiar cyfrowy Inicjatywy Trójmorza, Polski Instytut Spraw Międzynarodowych (Biuletyn) [online] 26 XI 2018 [dostęp: 29 X 2020], dostępny w internecie: <https:// pism.pl/publikacje/Wymiar_cyfrowy_Inicjatywy_Tr_jmorza>.

48 The Digital 3 Seas Initiative. Mapping the challenges to overcome, The Kosciuszko Institute, Krakow 2018, dostępny w internecie: <https://digital3seas.eu/wp-content/ uploads/2019/12/digital3seas_initiative_roadmap_report_2018.pdf $\rangle$. 
celnej na rzecz wsparcia tworzenia ośrodków e-handlu w pobliżu węzłów komunikacyjnych ${ }^{49}$. Ostatecznym i długofalowym celem współpracy w dziedzinie cyfrowej ma być budowa

[...] nowoczesnej, solidnej i bezpiecznej infrastruktury technologicznej, tworzącej wsparcie dla strategicznych inwestycji krajowych i zagranicznych, wspieranie rozwoju i wzmacnianie pozycji przedsiębiorstw działających $\mathrm{w}$ regionie. $3 \mathrm{SDH}$ umożliwi również stworzenie środowiska sprzyjającego tworzeniu danych przemysłowych, cyrkulujących w bezpiecznych ekosystemach w celu wykorzystania potencjału gospodarki opartej na danych informatycznych krajów Trójmorza ${ }^{50}$.

Działania zaplanowano $\mathrm{w}$ dwóch fazach: projektowo-planistycznej (2018-2019) oraz implementacyjnej (2020-). W czerwcu 2019 r. podczas szczytu Trójmorza w Lublanie ${ }^{51}$ współpraca cyfrowa stała się jednym z istotnych wątków, szeroko omawianym choćby przez prezydent Estonii Kersti Kaljulaid. Podczas październikowego szczytu w Tallinie w 2020 r. zagadnienia "Cyfrowego Trójmorza” zostały skorelowane z inicjatywą powołanego w maju 2019 r. Funduszu Trójmorza, z którego finansowane miałyby być takie projekty jak „dostępna dla sektora prywatnego i publicznego cyfrowa autostrada między krajami Trójmorza"52.

Nie należy pomijać społecznego wymiaru bezpieczeństwa cybernetycznego w obszarze Trójmorza. Jeszcze w 2018 r. z analiz wynikało dość duże zróżnicowane poziomu cyfryzacji społecznej państw, zarówno w wymiarze dostępu do technologii szybkiego przesyłu, pokrycia terytoriów państw zasięgiem, digitalizacji usług, wiedzy i umiejętności teleinformatycznych itd. ${ }^{53}$ Dostrzegalne było też odstawanie potencjałów państw Trójmorza

49 Inicjatywa Cyfroweǵo Trójmorza: wezwanie do.., s. 3 [dostęp: 29 X 2020].

50 The Digital 3 Seas Initiative. Mapping..., s. 12.

51 Szczyt inicjatywy Trójmorza w Lublanie, gov.pl, Ministerstwo Spraw Zagranicznych [online], 6 VI 2019 [dostęp: 29 X 2020], dostępny w internecie: <https://www.gov.pl/ web/dyplomacja/szczyt-inicjatywy-trojmorza-w-lublanie>.

52 A. Krzysztoszek, Szczyt Trójmorza: Ambitne plany gospodarcze czlonków inicjatywy. Polska zacieśnia wspótprace z Estonią, Euractiv.pl [online], 20 X 2020 [dostęp: 29 X 2020], dostępny w internecie: <https://www.euractiv.pl/section/polityka-regionalna/ news/trojmorze-szczyt-polska-estonia/ $>$.

53 Wymiar cyfrowy Inicjatywy.. 
od liderów cyfryzacji z Europy Zachodniej. Utrzymywanie, a właściwie pogłębianie się takich zjawisk powodowałoby powiększanie się zapóźnień i w konsekwencji wzrost wykluczenia cyfrowego. Znacząco i negatywnie odbiłoby się także na tempie rozwoju cywilizacyjnego i gospodarczego.

Nie jest przypadkiem, że jednym z liderów współpracy w dziedzinie cyfrowej jest Estonia. Oprócz wysokiego nasycenia nowoczesnym technologiami informacyjnymi państwo to również ma szczególne doświadczenia po uderzeniach w systemy informatyczne z pierwszej dekady XXI w. ${ }^{54}$

Inicjatywa Trójmorza jako projekt regionalny o silnym kontekście geopolitycznym wpisuje się w formułę przedsięwzięć funkcjonalnych. Na pierwszych szczytach, rozpoczynających współpracę zarysowano jej trzy kardynalne obszary: infrastrukturę logistyczno-transportową, kooperację $\mathrm{w}$ dziedzinie energetyki i rozwiązań informatyczno-telekomunikacyjnych. Wszystkie one sytuują się w szeroko pojmowanej domenie bezpieczeństwa, łącząc elementy bezpieczeństwa "negatywnego” (od) oraz bezpieczeństwa „pozytywnego" (do). Co warte podkreślenia, formuła współpracy w ramach Trójmorza charakteryzuje się podejściem funkcjonalnym, praktycznym i - w pewnym sensie - projektowym. Jak się wydaje, przywódcy państw regionu świadomie zrezyǵnowali bądź istotnie ograniczyli zakres podpisywanych porozumień politycznych o naturze ogólnej na rzecz koordynacji przedsięwzięć projektowych. W efekcie podkreślenia wymagają dwie kwestie: Inicjatywa Trójmorza opiera się na realnej współpracy, daleko też jest do tendencji przekształcania współpracy w formaty organizacji międzynarodowej. Jakkolwiek tworzone są pewne instytucje, np. Fundusz Trójmorza, mają jednak wyraźnie „usługowy” charakter. TSI z tej perspektywy wydaje się ciekawą i mającą wysoki potencjał formułą współpracy, charakteryzującą się dużą elastycznością. Unikanie sięgania po rozwiązania stricte polityczne (traktatowe) wydaje się właściwą formułą, podobnie jak nieeksponowanie kontekstów wykraczających poza obszar Unii Europejskiej. Można zakładać, że w przypadku wzrostu złożoności sieciowych w wyniku współpracy w sektorach ostatecznie wyłoni się rodzaj „reżimu” międzynarodowego,

54 Cyber Security in Estonia 2020 [online, dostęp: 29 X 2020], dostępny w internecie: <https://www.ria.ee/sites/default/files/cyber_aastaraamat_eng_web_2020.pdf $>$. 
który być może otworzy pespektywę instytucjonalizacji TSI i stopniowego jej przekształcania w pewien rodzaj organizacji międzynarodowej. Jednak scenariusz ten jest tyle odległy, co obarczony wieloma znakami zapytania.

\section{Bibliografia}

Ascari S., The Gas Target Model for the Visegrad 4 Region. Conceptual Analysis, Ośrodek Studiów Wschodnich, Warszawa, maj 2013,

Barash D. P., Webel Ch. P., Peace and Conflict Studies, SAGE, Thousand Oaks 2014, Bieliszczuk B., Trójmorze: wspótpraca na rzecz unijnego i regionalnego rynku gazu, Polski Instytut Spraw Międzynarodowych, 30 VI 2017 (Biuletyn PISM, 63 (1505)). Bieńczyk-Missala A., Polityka zagrraniczna Polski w setna rocznicę niepodległłości, „Rocznik Strategiczny" 2018/2019, t. 24, Wydawnictwo Naukowe Scholar, Warszawa 2019. Booth K., Theory of World Security, Cambridge University Press, Cambridge 2007. Buzan B., Wæver O., Regions and Powers: The Structure of International Security, Cambridge, Cambridge 2004.

Creveld M. van, A History of Strategy: From Sun Tzu to William S. Lind, Castalia House, Kouvola 2015.

Cyber Security in Estonia 2020 [online, dostęp: 29 X 2020], dostępny w internecie: 〈https://www.ria.ee/sites/default/files/cyber_aastaraamat_eng_web_2020.pdf $\rangle$. Inicjatywa Cyfrowego Trójmorza: wezwanie do nadania wspótpracy regionalnej silnego wymiaru cyfrowego, Instytut Kościuszki [online], VI 2018 [dostęp: 30 X 2020], dostępny w internecie: $<$ https://www.ik.org.pl/wp-content/uploads/white-paper_ inicjatywa_cyfrowego_trojmorza.pdf $\rangle$.

Komleva N. A., Limitrof kak geopolititcheskaya technologia, „Izvestia Uralskovo gosudarstvennovo universiteta”, series 1: „Problemy obrazovanija, nauki i kultury” 2010, issue $3(78)$.

Komleva N. A., Vojny v limitrofach: evolutsia technologij, „Prosyranstvo i vremija” 2015, issue 1-2 (19-20).

Lawler P., Peace Studies, Security Studies: An Introduction, ed. P. D. Williams, Routledge, Abingdon-New York 2008.

Mearsheimer J. J., Reckless states and realism, [w:] Realism and World Politics, ed. K. Booth, Routledge, Abingdon-New York 2011.

Nef J., Human Security and Mutual Vulnerability, International Development Research Centre, Ottawa 2002.

Nyga-Łukaszewska H., Bezpieczeństwo energetyczne: u źródeł chaosu semantycznego, [w:] Bezpieczeństwo energetyczne. Koncepcje, wyzwania, interesy, red. J.Gryz, A. Podraza, M. Ruszel, Wydawnictwo Naukowe PWN, Warszawa 2018.

O'Sullivan M. L., The Entanglement of Energy, Grand Strategy, and International Security, [w:] The Handbook of Global Energy Policy, ed. A. Goldthau, John Wiley \& Sons, Oxford 2013. 
Pawłowski K., Bukareszteńska Dziewiątka: współpraca państw wschodniej flanki NATO, „IEŚ Policy Papers” 2020, nr 4.

Pettit Ph., A Theory of Freedom: From the Psychology to the Politics of Agency, Polity Press, Cambridge 2001.

Podraza A., Problemy i zagrożenia a rozwój koncepcji bezpieczeństwa enerǵetycznego, [w:] Bezpieczeństwo enerǵetyczne. Koncepcje, wyzwania, interesy, red. J.Gryz, A. Podraza, M. Ruszel, Wydawnictwo Naukowe PWN, Warszawa 2018.

Przesłanie do uczestników Global Forum, gov.pl, Ministerstwo Obrony Narodowej [online] 7 VII 2017 [dostęp: 27 X 2020], dostępny w internecie: <https://www. gov.pl/web/obrona-narodowa/przeslanie-do-uczestnikow-global-forum-2 $>$.

Pumphre C.W., Introduction, [w:] The Energy and Security Nexus: A Strategic Dilemma, SSI, Carlisle PA, November 2012.

Reginia-Zacharski J., Wojna w świecie współczesnym. Uczestnicy - cele - modele - teorie, Wydawnictwo Uniwersytetu Łódzkiego, Łódź 2014.

Ruszel M., Kucharska A., Dywersyfikacja źródeł dostaw gazu ziemnego do państw Grupy Wyszehradzkiej - wyzwania i perspektywy rozwoju, Prace IEś 2020, nr 3.

Ruszel M., Bezpieczeństwo enerǵetyczne Polski. Wymiar teoretyczny i praktyczny, Rambler, Warszawa 2015.

Savic I., Shirkey Z. C., Uncertainty, Threat, and International Security: Implications for Southeast Asia, Routledge, Abingdon-New York 2017.

Shue H., Basic Rights, [w:] Contemporary Political Philosophy: An Anthology, ed. R. E. Goodin, Ph. Pettit, Blackwell, Malden-Oxford 2006.

Steele B. J., Ontological Security in International Relations: Self-Identity and the IR State, Routledge, London-New York 2008.

Stępniewski T., Inicjatywa Trójmorza: uwarunkowania geopolityczne i nowy model regionalnej współpracy, „Studia Europejskie - Studies in European Affairs” 2018, nr 2.

The Digital 3 Seas Initiative. Mapping the challenges to overcome, The Kosciuszko Institute, Krakow 2018.

Winzer Ch., Conceptualizing Energy Security, „EPRG Working Paper (1123) \& Cambridge Working Paper in Economics (1151)", July 2011. 